\title{
Az egészségműveltség definíciói
}

\author{
Definitions of Health Literacy
}

\author{
Szerző: Csizmadia Péter \\ Nemzeti Egészségfejlesztési Intézet
}

Beküldve: 2016.09.07.

\begin{abstract}
Összefoglaló: Az egészségmúveltség azokkal a kompetenciákkal és tudással foglalkozik, amelyek ahhoz szükségesek, hogy egy személy megfeleljen az egészség által támasztott követelményeknek egy modern társadalomban. A fogalom fontossága fokozatosan került elismerésre, azonban még nincs egyetértés az egészségmúveltség definíciójáról, amely behatárolja mérhetősége és összehasonlíthatósága esélyeit. A cikk célja röviden áttekinteni az egészségműveltséghez kapcsolódó definíciókat, és bemutatni az egészségmúveltség integrált modelljét, amely alapként szolgálhat e terület fejlesztését célzó intervenciók számára.
\end{abstract}

Kulcsszavak: egészségműveltség, egészségértés, kompetencia, egészségfejlesztés

Summary: Health literacy concerns the knowledge and competences of persons to meet the complex demands of health in modern society. Although its importance is increasingly recognised, there is no consensus about the definition of health literacy or about its conceptual dimensions, which limits the possibilities for measurement and comparison. The aim of the study is to review definitions and models on health literacy and to show an integrated definition of health literacy. This model can serve as a basis for developing health literacy enhancing interventions.

Keywords: health literacy, competence, health promotion

\section{AZ EGÉSZSÉGMŰVELTSÉG FOGALMÁNAK MEG- JELENÉSE ÉS DEFINÍCIÓI}

Az egészségmúveltség kifejezés 1970-es években jelent meg és nyert folyamatos jelentőséget a népegészségügyben és az egészségügyi ellátásban. Egy tanulmány, amely áttekintette az egészségmüveltség szakirodalmát nem kevesebb, mint 17 különböző definíciót számlált össze. ${ }^{1}$ Ebből az egyik leggyakrabban idézett a WHO meghatározása, amely szerint az egészségműveltség „az emberek kognitív és szociális készsége (skills), amely meghatározza az egyének motivációját és az egyének képességét (ability), amely segítségével hozzáférnek, megértik és felhasználják azokat az információkat, amelyek elősegítik és fenntartják jó egészségüket." ${ }^{2}$

Nemrégiben jelent meg folyóiratunkban, „Az egészségműveltség értelmezése és fő kihívásai a mai ma- gyar társadalomban" című cikk, amely a WHO 7. Globális Egészségfejlesztési Konferenciájának megállapításaiból idézi (Nairobi 2008). Eszerint „Az egészségmúveltség olyan kognitiv és szociális készségek halmaza, amelyek meghatározzák az egyes emberek motivációját és képességét, hogy hozzáférjenek, megértsék és felhasználják azokat az információkat, amelyek elősegítik a jó egészség fenntartását és fejlesztését. Az egészségmúveltség többet jelent, mint kiadványok olvasását vagy sikeres vizitek lebonyolítását. Az egészségműveltségnek az egészséggel kapcsolatos információ hozzáférésének és felhasználási képességének javítása révén döntő szerepe van az egyén egészség feletti kontrolljában." ${ }^{3}$

A konferencia által ilyen módon értelmezett egészségműveltség messze túllép az egészségnevelés szűkebb értelmezésein, az egyéni magatartásra 
összpontosító kommunikáción, és - például az egészséggel kapcsolatos információk hozzáférésének javítása révén - azokra a környezeti, politikai és társadalmi tényezőkre is irányul, amelyek az egészség meghatározói.

Az egészségműveltség populáció szintű megközelítését támogató elméletek közül fontos megemlíteni Nutbeam modelljét, amely az egészségmúveltség három típusát vázolja fel. Az első a funkcionális egészségmúveltség, az alapkészségeket tartalmazza az írás és olvasás tekintetében, amelyek szükségesek a hatékonysághoz a mindennapi helyzetekben. Az interaktív egészségműveltségről fejlettebb kognitív és múveltségi készségek esetén beszélhetünk, amit a szociális készségekkel együtt, aktívan lehet használni változó körülmények között, a társas helyzetekben, információszerezésnél, vagy éppen a különböző kommunikációs formák megértésénél. A kritikai egészségmúveltségnél olyan kognitív készségek kerülnek alkalmazásra a társas készségekkel együtt, amelyek révén az információk kritikus elemzésére kerül sor, és azokat a saját élet, élethelyzetek feletti kontroll megszerzésére használják az emberek. $^{4}$

Kickbusch és szerzőtársai egészségműveltségről szóló definitív cikke a kompetenciák négy nagy csoportját állította fel az egészségműveltséggel kapcsolatban:

1. Alapvető egészségkompetenciák: az egészségvédő, betegségmegelőző és egészségfejlesztő magatartás képességei, az öngyógyítás (öngyógyszerezés, az egészség orvosi segítség nélküli visszanyerési képessége).

2. Páciens kompetenciák: az egészségügyi rendszerben az eligazodás képessége, aktív tárgyalópartnerként történő fellépés az egészségügyi szakemberekkel való kapcsolatban.

3. Fogyasztói kompetenciák: egészséget támogató döntések képessége a javak és szolgáltatások megvásárlása során, és ha szükséges, a fogyasztói jogok érdekérvényesítése.

4. Állampolgári kompetenciák: tudatos szavazói magatartás, az egészséggel kapcsolatos jogok ismerete és azok érdekében fellépés, részvétel egészséget támogató- vagy betegszervezetekben. $^{5}$

\section{AZ EGÉSZSÉGMŰVELTSÉG INTEGRÁLT MO- DELLE}

2012-ben Sorensen és munkatársai az egészségmüveltség szakirodalmát áttekintő tanulmány összegzésképpen az egészségműveltség integrált modelljét igyekeztek megalkotni. ${ }^{6}$ A szerzők véleménye szerint a létező modellek nagy része statikus és nem veszi figyelembe az egészségműveltség folyamat jellegét, amely magában foglalja a hozzáférést, a megértést, és az információátadást.

Az integrált modell a következő meghatározásra épül: „Az egészségműveltség kapcsolatban áll a műveltséggel és hozzájárul ahhoz, hogy az emberek tudása, motivációja és kompetenciája alkalmassá váljon az egészség információkhoz való hozzáféréshez, azok megértéséhez, értékeléséhez (appraise) és alkalmazásukhoz a mindennapi életben bekövetkező véleményalkotás és döntéshozatal idején az egészségügyi ellátás, a prevenció és az egészségfejlesztés területén, annak érdekében, hogy fenntartsuk vagy javítsuk az életminőséget életünk során." [1. ábra] A konstrukció középpontjában az egészségműveltség folyamata áll, amely négy kompetenciát igényel:

1. A hozzáférés arra a képességre vonatkozik, hogy kérünk, keresünk és hozzájutunk egészséginformációhoz.

2. A megértés azt a képességet takarja, amellyel megértjük a kapott egészséginformációt.

3. Az értékelés olyan képesség, amely interpretálja, szűri, megítéli és értékeli a kapott egészséginformációt.

4. Az alkalmazás arra a képességre vonatkozik, amellyel kommunikáljuk és használjuk az információt, döntést hozzunk annak érdekében, hogy fenntartsuk vagy javítsuk az egészségünket.

Ez a folyamat ismeretet és jártasságot eredményez, amely képessé teszi a személyt, hogy eligazodjon az egészség folyamat három fő területén, az egészségügyi ellátásban, a prevenció és az egészségfejlesztés rendszerében. Mindezt úgy, hogy figyelembe veszi, hogy az egyén a munkahely, az oktatási rendszer, a politika és a gazdaság szereplője. A modell ugyanis magában foglalja azokat a tényezőket is, amelyek hatnak az egészségmúveltségre, azaz a társadalmi és környezeti meghatározókat, mint például a demográfiai helyzetet, a kultúrát, a nyelvet, vagy a politikai helyzetet. 


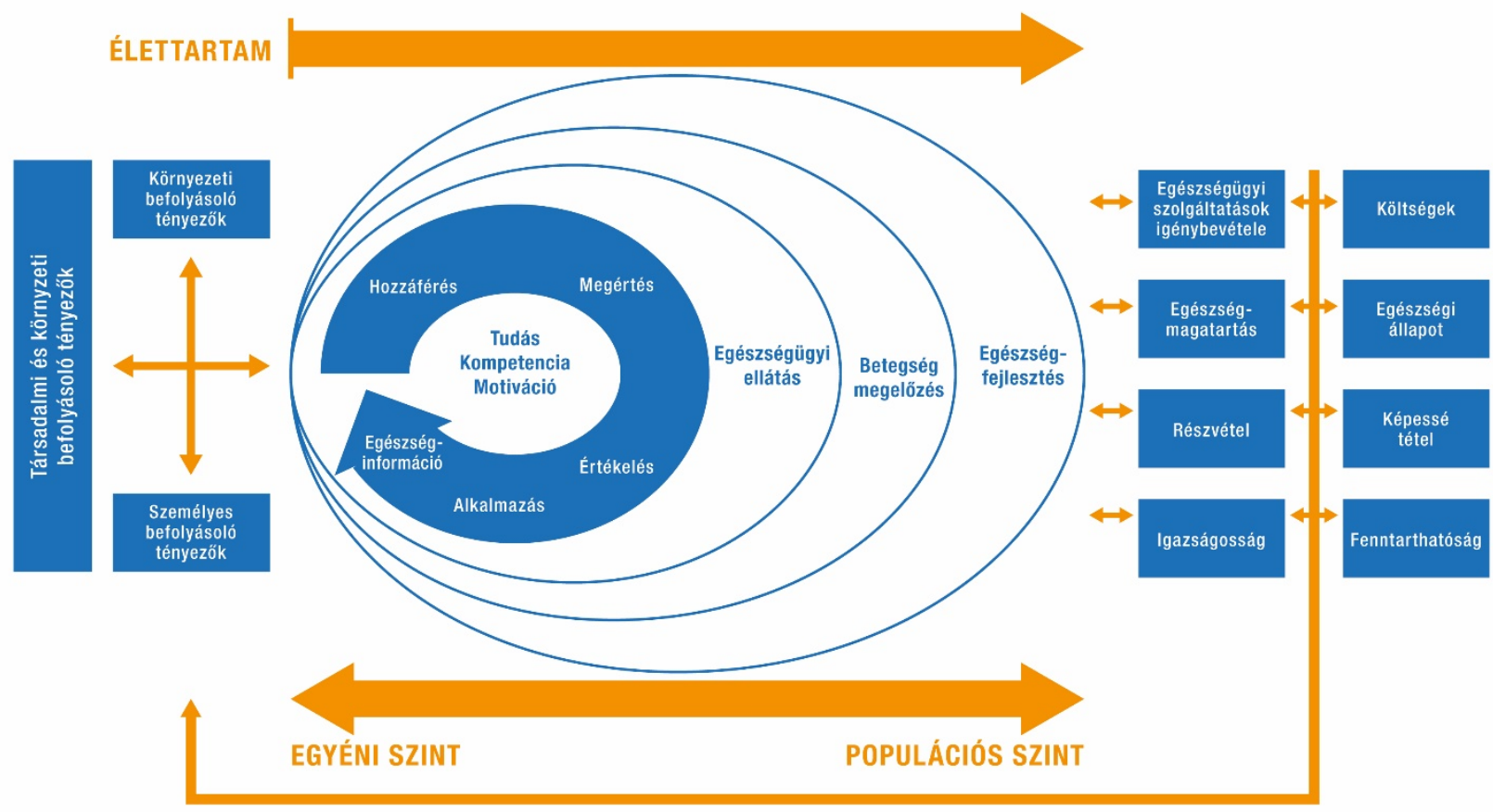

Forrás: Sorensen et. al. Health Literacy and public Health: A systematic review and integration of definitions and models. BMC Public Health 2012, 12:80

Az egészségmúveltség folyamata során mindhárom terület segíti az embereket, hogy befolyást gyakoroljanak a saját egészségük felett, alkalmazzák az általános múveltségüket, a matematikai képességeiket, hogy beszerezzék a szükséges egészség információkat, megértsék, kritikusan elemezzék és értékeljék azokat, hogy önállóan cselekedjenek, valamint hogy legyőzzék az egészség személyes, strukturális, társadalmi és gazdasági akadályait. Ahogy a környezeti kihívások, úgy az egyének képessége is időről időre változik, hogy eligazodjon az egészségügyi rendszerben. Az egészségmúveltség tehát függ a kognitív és a pszichoszociális fejlődéstől, illetve a korábbi és jelenlegi tapasztalatoktól. Az egészségmúveltségben való jártasság és a kompetenciák fejlődnek az életpálya folyamán, így élethosszig tartó tanulásként is értelmezhetők. Az egészségmúvelt- ség tehát egy eszköznek tekinthető, amely támogatja a képessé tétel folyamatát az ellátás, a prevenció és az egészségfejlesztés területén.

Ez a tágabb értelmezés nem csak az egyéni életmóddal kapcsolatos döntéseket hangsúlyozza, hanem tudatosítja az egészség meghatározóinak szerepét és bátorítja a meghatározók kedvező irányú változását elősegítő egyéni és közösségi akciókat olyan módszerekkel, amelyek túllépnek az információterjesztésen és ösztönzik az interakciót, a részvételt és a kritikai elemzést. Így az egészségmúveltség egyéni és társadalmi hasznot eredményez, mint a hatékony közösségi akcióra való felkészítést és a társadalmi tőke növeléséhez való hozzájárulást.

Egyéni szinten az alacsony egészségmúveltségből fakadó nem hatékony kommunikáció rossz minőségú szolgáltatást és a páciensek biztonságát veszé- 
lyeztető helyzeteket eredményezhet az egészségügyi ellátásban. Az egészségműveltség befolyásolja az egészségmagatartást és az egészségügyi szolgáltatások igénybevételét, ezáltal hat a társadalom egészségi állapotára és az egészségre fordított költségekre, populációs szinten hozzájárul a méltányosság elősegítéshez, a népegészségügy fenntarthatóságához. A magas egészségmúveltség segíti a nagyobb autonómiát, a személyes képessé tételt, ami egyfajta fejlődésként fogható fel egy jobb életminőség felé. Emellett a magas egészségmúveltséggel rendelkező személyek képesek arra, hogy részt vegyenek a magán- és közbeszédben az egészségről, a gyógyszerekről, a tudományos eredményekről, a kultúráról folyó diskurzusokban. Ezen a módon az egészségmúveltség pozitív hatást gyakorol a háztartásokra, a munkahelyekre, a társadalomra és a kultúrára is.

\section{AZ EGÉSZSÉGMŰVELTSÉG HAZAI DEFINIÁLÁSA}

A nemzetközi definíciós kísérletek után néhány szót a hazai helyzetről is szükséges ejteni. Az egészség- múveltség kifejezés természetesen hazánkban is megjelent és a hazai szakirodalomban gondot okoz a health literacy kifejezés magyarra fordítása. Sokan a műveltség helyett az egészségértés kifejezés használatát javasolják. Véleményem szerint azonban az értés kifejezés csak a műveltség egy szeletére fókuszál, nem eléggé hangsúlyozza az egészségmúveltség folyamat jellegét, interaktivitását. Az egészségmúveltség alternatívájaként az egészségjártasság szó is felbukkan szakmai anyagokban. Az online magyar értelmező szótár a jártasságot, megszerzett szaktudás, illetve gyakorlottság néven határozza meg. Úgy vélem ez a szinonima is inkább szúkíti a múveltség szó jelentését, hiszen a befejezettséget hangsúlyozza. Ezért - ameddig nem áll rendelkezésre jobb - az egészségmúveltség kifejezést célszerü használni.

Az egészségmúveltség integrált modellje hozzájárulhat az egészségügyi ellátórendszer hatékonyságának javításához, a prevenció és az egészségfejlesztés hangsúlyozásával pedig az egészségi állapot tartós javulásához.

\footnotetext{
${ }^{1}$ Sorensen et. al. Health Literacy and public Health: A systematic review and integration of definitions and models. BMC Public Health 2012, 12:80

${ }^{2}$ Nutbeam, D. Health promotion glossary. Health Promotion International, 13, 349-364. 1998.

3 Taller Á et al. Az egészségműveltség értelmezése és fő kihívásai a mai magyar társadalomban. Egészségfejlesztés. 2015.1-2. szám és 2015. 3 szám.

${ }^{4}$ Nutbeam D: Health literacy as a public goal: a challenge for contemporary health education and communication strategies into the 21st century. Health Promot Int 2000, 15(3):259-267

${ }^{5}$ Kickbusch I., Wait S., Maag D.: Navigating Health. The role of Health Literacy. London: Alliance for Health and the Future, 2006

${ }^{6}$ Sorensen et. al. Health Literacy and public Health: A systematic review and integration of definitions and models. BMC Public Health 2012, 12:80
} 